\title{
Effects of different substrates on the growth and composition of periphyton in the low saline groundwater system
}

\author{
K.S. Vijay Amirtharaj ${ }^{a, *}$, B. Ahilan ${ }^{\mathrm{b}}$, C.B.T. Rajagopalsamy ${ }^{\mathrm{c}}$, Rosalind M. George ${ }^{\mathrm{d}}$, P. Jawahar \\ a Mariculture Research Farm Facility, Department of Aquaculture, Fisheries College and Research Institute, \\ Thoothukudi 628105 India \\ b Dr.M.G.R Fisheries College and Research Institute, Ponneri 601204 India \\ c Department of Aquaculture, Dr. M.G.R. Fisheries College and Research Institute, Ponneri 601204 India \\ d Department of Fish Pathology and Health Management, Fisheries College and Research Institute, \\ Thoothukudi 628008 India \\ e Tamil Nadu Dr. J. Jayalalithaa Fisheries University, Nagapattinam 611002 India
}

*Corresponding author, e-mail: vijayamirtharaj@tnfu.ac.in, ksvijay444@gmail.com

Received 19 Dec 2020

Accepted 28 Jun 2021

\begin{abstract}
The growth and composition of periphyton in low saline groundwater (5 ppt) were evaluated using 5 different substrates: split bamboo poles (SBP), green shade net (GSN), high density polyethylene (HDPE) sheets, low density polyethylene (LDPE) sheets, and polyvinyl chloride (PVC) pipes). The effect of substrate type, submersion time, and depth was evaluated. The average submersion depth of all the substrates was maintained at $88.27 \mathrm{~cm}$, and this trial was conducted for 60 days. Chlorophyll a, dry weight, ash, ash free dry weight, and periphyton diversity were analyzed. The growth of periphyton in terms of chlorophyll a value on different substrates has revealed a higher mean value for bamboo substrate $\left(6.82 \pm 2.79 \mu \mathrm{g} / \mathrm{cm}^{2}\right)$, followed by green shade net, HDPE, LDPE, and PVC with values of $5.24 \pm 2.27 \mu \mathrm{g} / \mathrm{cm}^{2}, 4.64 \pm 2.06 \mu \mathrm{g} / \mathrm{cm}^{2}, 4.51 \pm 2.08 \mu \mathrm{g} / \mathrm{cm}^{2}$, and $3.10 \pm 1.57 \mu \mathrm{g} / \mathrm{cm}^{2}$, respectively. The mean values of dry weight recorded were $1.81 \pm 0.78 \mathrm{mg} / \mathrm{cm}^{2}, 1.65 \pm 0.70 \mathrm{mg} / \mathrm{cm}^{2}, 1.29 \pm 0.56 \mathrm{mg} / \mathrm{cm}^{2}, 1.32 \pm 0.57 \mathrm{mg} / \mathrm{cm}^{2}$, and $0.78 \pm 0.45 \mathrm{mg} / \mathrm{cm}^{2}$ for SBP, GSN, LDPE, HDPE, and PVC substrates, respectively. In all substrates, there was a significant difference observed in the development of periphyton over time $(p<0.05)$. There was no significance $(p>0.05)$ observed in Chlorophyll a value with depth in all 5 different substrates.
\end{abstract}

KEYWORDS: artificial substrate, periphyton, saline groundwater, dry weight, ash free, chlorophyll a, aquaculture

\section{INTRODUCTION}

Saline groundwater is unsuitable for any traditional agriculture practices, and the non-utilization of this saline water will cause secondary salination and waterlogging condition with poor water quality [1]. Pumping of this saline water and its evapo-transpiration in the landlocked area will lower down the water table to a safer root zone of the plants. This evapotranspiration is economically viable through aquaculture practice along with income generation [2].

The term 'periphyton' has been defined by different authors; according to Wetzel, it is the microfloral community living attached to the surface of submerged objects in water [3], and this does not include fungal, bacterial, protozoan, and other attached animal components attached to the substrate. The German word 'aufwuchs' means plants and animals that encrust hard surface, including all the organisms that are attached to or move upon a submerged substrate but do not penetrate it, whereas Reid et al and Wetzel have referred to periphyton as the total assemblage of any sessile or attached organisms on any substrate $[4,5]$. There are different terms used by different authors to refer to the unattached organisms and the mobile or creeping organisms associated with periphyton as 'euperiphyton' and 'pseudoperiphyton or metaphyton', respectively. Azim et al have coined the universally accepted definition for the term 'periphyton' as the entire complex of attached aquatic biota on submerged substrates, including associated non-attached organisms and detritus. Thus, the periphyton community comprises bacteria, fungi, protozoa, phytoplankton, zooplankton, benthic organisms, organic detritus, and a range of other invertebrates and their larvae [6].

In many water bodies, the contribution of the periphyton community to production is greater than that of the phytoplankton. In a study that compared the primary productivity of a turbid and clear lake, phytoplankton were found to account for $96 \%$ of the total annual production in the turbid lake while epipelon contributed $77 \%$ in the clear lake. The contribution of periphyton to annual primary productivity is as high as $1 \mathrm{kgC} / \mathrm{m}^{2}$. The high value of periphyton productivity is found in coral reef system with values in a range of $1-3 \mathrm{~g} \mathrm{C} / \mathrm{m}^{2} /$ day, and the highest value of periphyton production is reported in acadja systems (7.9 $\mathrm{g} \mathrm{C} / \mathrm{m}^{2} /$ day), which is 4.5 times higher than that of the lagoon phytoplankton community [6]. In traditional aquaculture, strategies are adopted for reducing inputs and increasing efficiencies of aquaculture production through optimization and exploitation of the phytoplankton-based food web. The periphytonbased food web offers possibilities for further optimiz- 
ing input utilization in extensive and semi-intensive aquaculture ponds.

To enhance periphyton production, hard substrates can be used in the pond's euphotic zone. Any materials that provide surface area can be used in aquaculture ponds to support periphyton growth. The new primary production and benthic secondary production of the attached communities fostered by the artificial substrate support the new food web, a part of which ends up as fish biomass [7]. Quantitative and qualitative growth of periphyton on substrates depends on factors like (i) submersion time, (ii) substrate type, and (iii) light intensity. Periphyton-based aquaculture is widely tested in freshwater farming, marine, and brackish water farming, but its use is only limited to shrimp and abalone [8]. The present study is the preliminary assessment of the feasibility of the periphyton growth using different substrates in low saline groundwater. In this study, the most suitable substrate for better periphyton growth and composition for low saline farming culture system was evaluated.

\section{MATERIALS AND METHODS}

\section{Experimental design}

The experiment was carried out in 5 tons of outdoor cement tanks using 5 ppt saline groundwater. The tanks were treated with chlorine and filled with groundwater, and 10 days before the erection of the substrate into the cement tanks, the tank water was inoculated with 101 of plankton-enriched water from fish culture tanks and fertilized with urea (12 gm/application) and triple superphosphate ( $8 \mathrm{gm} /$ application) once in every 2 days. Five different substrates were used in this experiment: (a) $4 \mathrm{~cm}$ width split bamboo poles, (b) $10 \mathrm{~cm}$ width green shade net ( $1 \mathrm{~mm}$-mesh), (c) $10 \mathrm{~cm}$ width low density polyethylene (LDPE) sheet, (d) $10 \mathrm{~cm}$ width high density polyethylene (HDPE) sheet, and (e) 1 inch Polyvinyl Chloride (PVC) pipe. Throughout the experimental period, the mean submersion depth of the substrates ( \pm SE) was maintained at $88.27 \pm 0.15 \mathrm{~cm}$. The 5 different substrates were fabricated as strings with 10 units each using a head and foot rope. For vertical positioning of the substrate in a circular cement tank, the foot rope was provided with molded cement stones as sinkers, and the fabricated substrate strings were placed inside the 3 circular cement tanks with vigorous aeration.

The periodical analysis was done from the periphyton samples for dry matter (DM), pigment concentration (Chlorophyll a), ash free dry matter (AFDM), and autotrophic index (AI) every 10 days following the standard methods [9]. From each tank, a substrate was taken from the 5 different stringed substrates (3 bamboo, 3 green shade net, 3 LDPE, 3 HDPE, and 3 PVC), and $2 \times 2 \mathrm{~cm}^{2}$ samples of periphyton were taken at every 3 different depths $(10,40$, and $70 \mathrm{~cm})$. The area was scrapped carefully using a scalpel blade to remove all the periphyton without affecting (visually) the substrate $[10,11]$. After sampling, the substrates were replaced in their original position, marked, and excluded from subsequent sampling.

\section{Sample analysis}

Water temperature, $\mathrm{pH}$, and dissolved oxygen were measured daily at 8.00 am using YSI professional handheld multi-parameter kit at the water depth of $20 \mathrm{~cm}$. Salinity was checked before the erection of the substrate and at every 10-day interval. Chlorophyll a content from the collected periphyton sample was determined following standard methods [9]. Upon removal of the periphyton from the substrate, the sample was immediately transferred to labeled tubes containing $10 \mathrm{ml}$ 90\% acetone, sealed, and transferred to the laboratory and stored in a refrigerator overnight. In the next morning, the samples were homogenized for $30 \mathrm{~s}$ in a tissue grinder, again refrigerated for $4 \mathrm{~h}$, and centrifuged for $10 \mathrm{~min}$ at 2000-3000 rpm. The supernatant was carefully transferred to $1 \mathrm{~cm}$ glass cuvettes, and absorbance was measured at 663, 645, and $630 \mathrm{~nm}$ using a spectrophotometer. One sample of the 2 collected samples was used for the determination of total dry mater and ash content of the periphyton sample. The sample was collected in pre-weighed and labeled aluminum foil piece, dried at $105^{\circ} \mathrm{C}$ in a hot air oven for $1 \mathrm{~h}$ until constant weight, and kept in a desiccator. The dry matter was transferred to a muffle furnace, ashed at $450^{\circ} \mathrm{C}$ for $6 \mathrm{~h}$, and weighed. Dry matter, ash free dry matter, and ash content were determined by weight difference.

Taxonomic analysis of periphyton was done in $2 \times 2 \mathrm{~cm}^{2}$ periphyton samples collected at the depth of $25 \mathrm{~cm}$ from different substrates. Samples were collected periodically for analysis once every 10 days after the erection of the substrate. The periphyton sample was suspended in $50 \mathrm{ml}$ distilled water and preserved in $5 \%$ buffered formalin in sealed plastic vials. After vigorous shaking, $1 \mathrm{ml}$ of the preserved sample was transferred to Sedgwick-Rafter cell (S-R cell) divided into 1000 squares. Ten squares were randomly selected for the identification of the algae using an inverted Microscope. Taxa were identified using keys from Manual of Freshwater Biota by Datta Munshi et al [12]. The water sample was also determined for plankton once every 10 days by filtering 51 of water from the circular tanks; samples were taken at 2 different locations of the tank using $45 \mu \mathrm{m}$ plankton net and preserved in 5\% formalin. Further analysis of the taxa was performed the same as described for periphyton.

\section{Statistical analysis}

The assumption of chlorophyll a data from different substrates was checked for its normality and homogeneity using Shapiro-Wilk and Levene Statistics, re- 
spectively. ANOVA test was performed for the variables from different substrates and evaluated for its significance in submersion depth, submersion time, and substrate type using SPSS 25.0 statistical analysis software. Dry matter, ash free dry matter, and autotrophic index for different substrates depending on time and depth were also analyzed for their significance using one-way ANOVA. The substrate wise plankton taxonomic classification was analyzed using Kruskal Wallis non-parametric one-way ANOVA, and day wise plankton taxa were analyzed by one-way ANOVA using SPSS 25.0 statistical analysis software.

\section{RESULTS}

The plankton composition among all the substrates was observed to be dominated by only 3 different groups belonging to Bacillariophyceae, Chlorophyceae, and Euglenophyceae. There was a significant difference observed in the number of algal periphyton in different substrates $(p<0.05)$. The mean values of overall algal composition were observed to be highest in the split bamboo substrate ( 9589 cells $/ \mathrm{cm}^{2}$ ), and the lowest value of 3981 cells $/ \mathrm{cm}^{2}$ was observed in the green shade net. The multiple pairwise comparisons of substrates for individual genera have shown significance for some pairs of substrates (Fig. 1ab).

Chlorophyll a, dry matter, and ash free dry matter have varied significantly among submersion time according to ANOVA results $(p<0.05)$. The growth of periphyton was observed with the highest mean values of chlorophyll a $\left(7.1 \pm 0.23 \mu \mathrm{g} / \mathrm{cm}^{2}\right)$ during 60 days of sampling. The lowest mean value was observed during 10 days of sampling $\left(1.64 \pm 0.06 \mu \mathrm{g} / \mathrm{cm}^{2}\right)$, followed by an increase during 20 days $\left(2.74 \pm 0.15 \mu \mathrm{g} / \mathrm{cm}^{2}\right)$ and 30 days $\left(4.39 \pm 0.18 \mu \mathrm{g} / \mathrm{cm}^{2}\right)$ of sampling. The mean values were observed to be almost the same for 40 days $\left(6.43 \pm 0.23 \mu \mathrm{g} / \mathrm{cm}^{2}\right)$ and 50 days $\left(6.48 \pm 0.28 \mu \mathrm{g} / \mathrm{cm}^{2}\right)$ of sampling. Submersion time was found to have a significant influence on the growth of periphyton (Fig. 2).

The multiple compassion test of Tukey's HSD (Tukey's Honestly Significant Difference test) proved that there is a significant difference between different days of sampling in the values of chlorophyll a development $(p<0.05)$, whereas there is no significant difference observed in chlorophyll a between the comparison of 40 days with 50 days $(p>0.05)$ and 60 days $(p>0.05)$ of sampling. The mean value of chlorophyll a was high at $10 \mathrm{~cm}$ depth of the substrates $\left(5.08 \pm 0.28 \mu \mathrm{g} / \mathrm{cm}^{2}\right)$, and the mean values were $4.81 \pm 0.26 \mu \mathrm{g} / \mathrm{cm}^{2}$ and $4.69 \pm 0.25 \mu \mathrm{g} / \mathrm{cm}^{2}$ at 40 and $70 \mathrm{~cm}$ depth of the substrates, respectively. The Post Hoc multiple comparison tests using the chlorophyll a value of different substrates at different depths revealed that there is no significant difference ( $p>0.05$ ) observed in the values obtained at different depths from different substrates.
Among all of the 5 different substrates used for the study, Tukey's HSD test showed the chlorophyll a value on different substrates has revealed the highest mean value for bamboo substrate $\left(6.82 \pm 2.79 \mu \mathrm{g} / \mathrm{cm}^{2}\right)$, followed by green shade net, HDPE, LDPE, and PVC with values of $5.24 \pm 2.27 \mu \mathrm{g} / \mathrm{cm}^{2}, 4.64 \pm 2.06 \mu \mathrm{g} / \mathrm{cm}^{2}$, $4.51 \pm 2.08 \mu \mathrm{g} / \mathrm{cm}^{2}$, and $3.10 \pm 1.57 \mu \mathrm{g} / \mathrm{cm}^{2}$, respectively. The Tukey's HSD analysis using SPSS in multiple comparisons has shown a significant difference between substrates, and bamboo has significantly different when compared with the other substrates $(p<$ 0.05 ), whereas there is no significance observed in multiple comparisons between green shade net and HDPE ( $p$-value 0.607), green shade net and LDPE ( $p$ value 0.421 ) sheets and in the comparison between LDPE and HDPE sheets, the $p$-value was $>0.05$. The dry weight values obtained from the different substrates were almost normally distributed, and the homogeneity test of variances showed values higher than 0.05 . There is a significant difference observed in the dry weight values of periphyton obtained from different substrates. The highest values were recorded in SBP, and the lowest value was observed in PVC. The means of ash, AFDW, and AI (Table 1) varied significantly based on substrate type $(p<0.05)$.

The inland low saline groundwater in Ecuador used for post larval rearing of shrimp resulted in low survival, and analyses revealed low potassium content [13]. The inland saline groundwater does not have the same ionic composition as seawater [14]. In the present conducted trial, though there was no chemical modulation of water, the major water quality parameters $(\mathrm{pH}$, salinity, and alkalinity) were observed to be at optimal levels throughout the study period.

\section{DISCUSSION}

The development of layers on a clean substrate is initiated by the deposition of dissolved organic substances, mainly amino acid and mucopolysaccharides [15] followed by bacteria and diatoms. Algae are very diverse and cosmopolitan. There are approximately 26000 algal species described in 24 classes [16]. In pond habitat, the periphyton taxa are dominated by Bacillariophyceae, Chlorophyceae, Cyanophyceae, Euglenophyceae, zooplankton, and invertebrates, and in estuary and sea, the periphyton taxa is dominated by Bacillariophyceae, Chlorophyceae, Cyanophyceae, Rhodophyceae, and Phaeophyceae [6]. In low saline groundwater conditions, the colonization of periphyton varied from substrates, and the maximum colonization was observed in split bamboo substrate compared to the other substrates used in the present study. In all the substrates, the periphyton taxa were dominated by Bacillariophyceae, Chlorophyceae, and Euglenophyceae. In all of 5 different substrates, the periphyton taxa were dominated by Euglenophyceae under low saline groundwater conditions in circular 
(a)
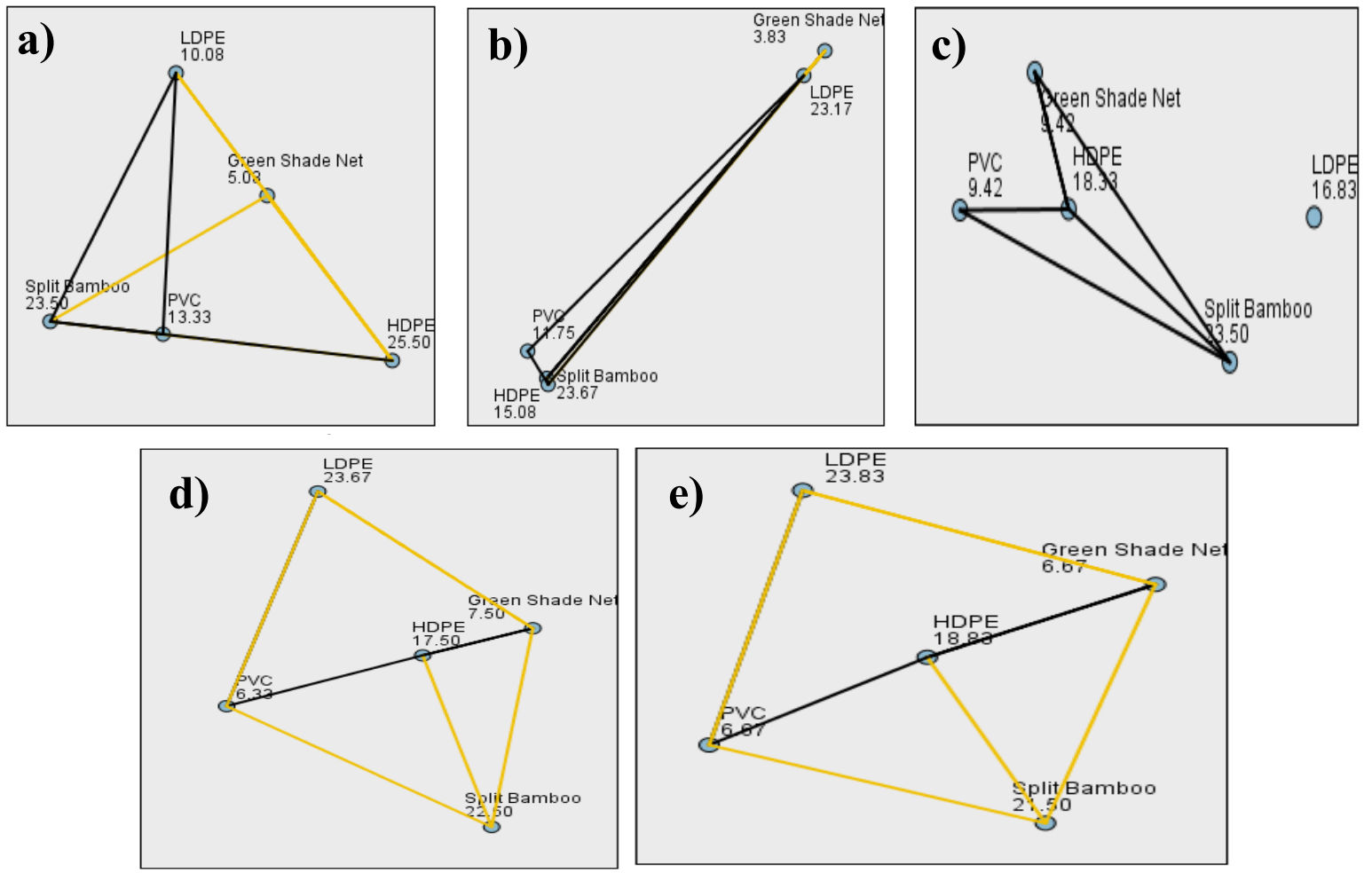

(b)
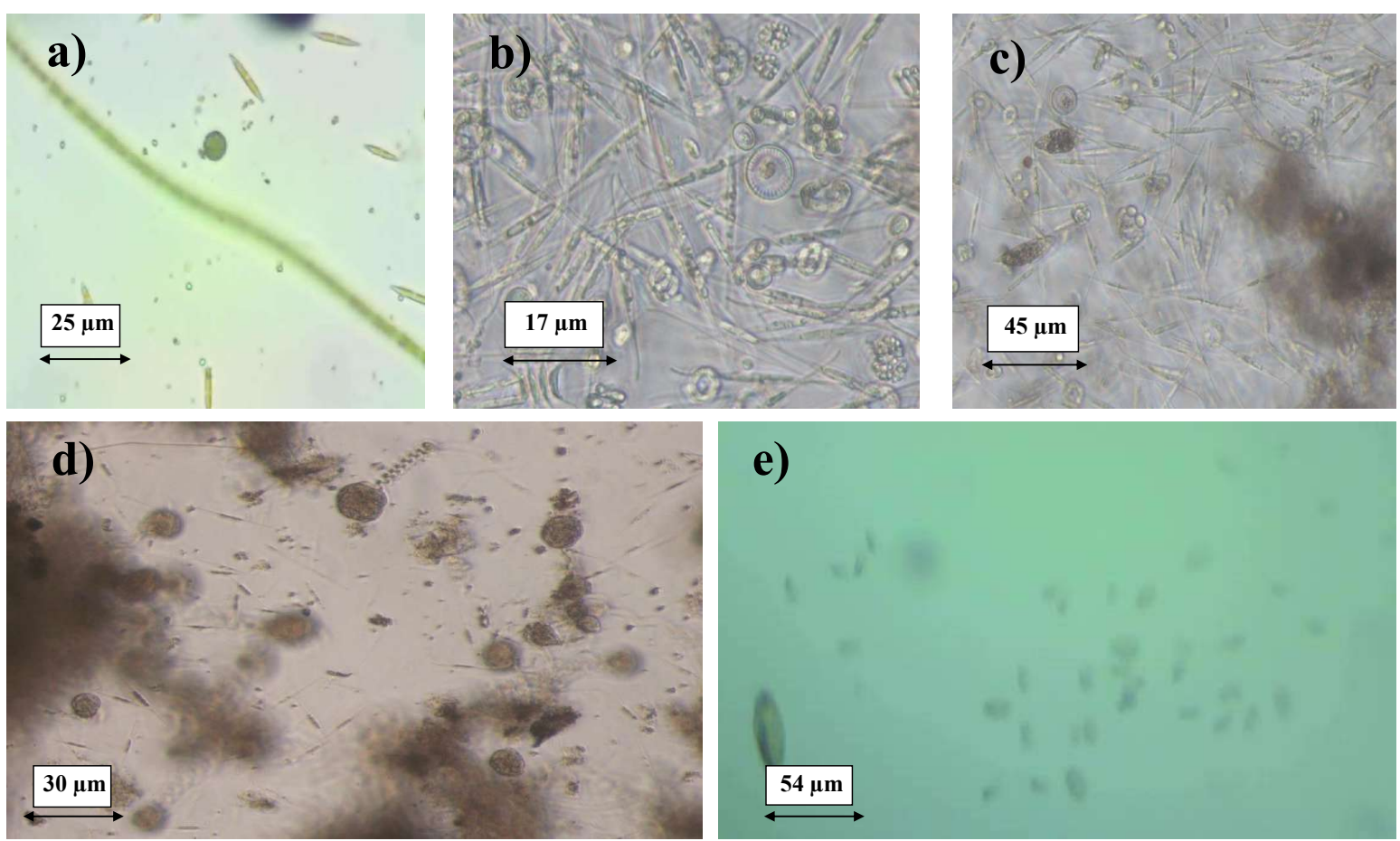

e)

Fig. 1 (a) Pairwise comparison of substrates for different plankton genera: a. Achnanthes; b. Cylotella; c. Nitzschia; d. Ankistrodesmus; and e. Euglena. (b) Microscopic morphology of periphytic plankton: a. Achnanthes; b. Cylotella; c. Nitzschia; d. Ankistrodesmus; and e. Euglena. 


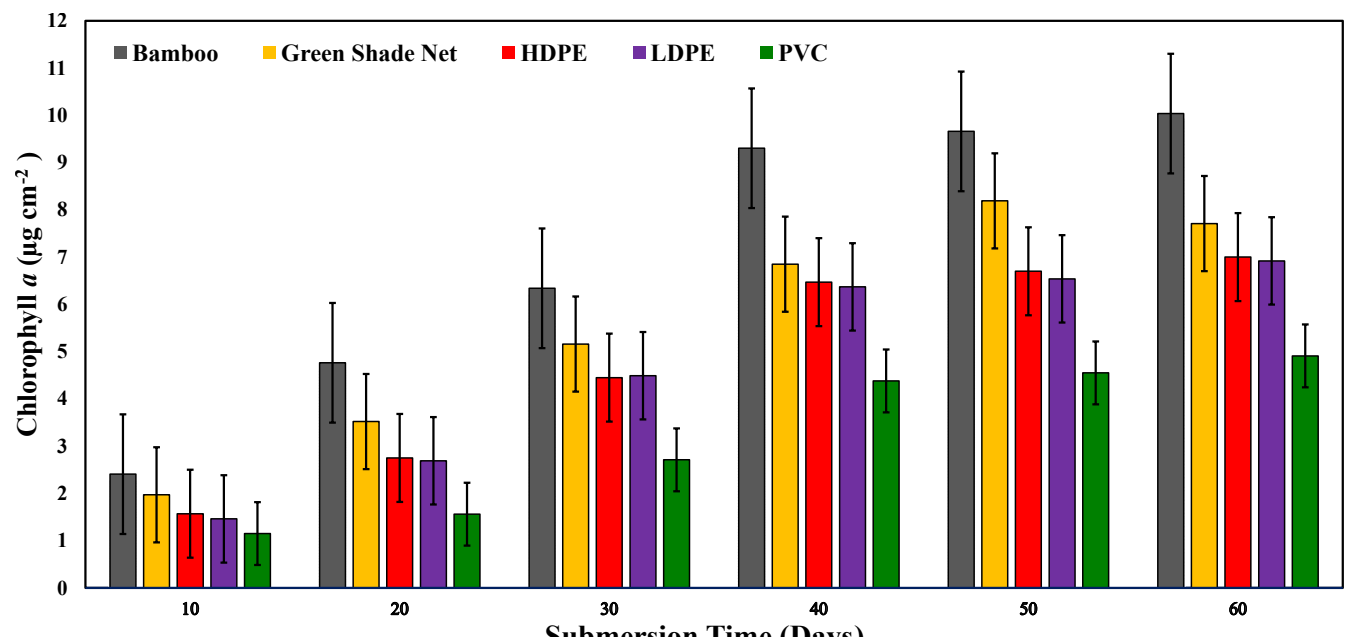

Fig. 2 Impact of submersion time on the growth of periphyton in terms of chlorophyll a.

Table 1 Periphyton biomass in different substrates.

\begin{tabular}{lcccr}
\hline Substrate & $\begin{array}{c}\text { Dry weight } \\
\left(\mathrm{mg} / \mathrm{cm}^{2}\right)\end{array}$ & $\begin{array}{c}\text { Ash } \\
\left(\mathrm{mg} / \mathrm{cm}^{2}\right)\end{array}$ & $\begin{array}{c}\text { AFDW } \\
\left(\mathrm{mg} / \mathrm{cm}^{2}\right)\end{array}$ & AI \\
\hline Split bamboo & $1.18 \pm 0.78$ & $0.63 \pm 0.29$ & $1.18 \pm 0.49$ & $169 \pm 32.6$ \\
Green shade net & $1.65 \pm 0.70$ & $0.58 \pm 0.26$ & $1.07 \pm 0.44$ & $204 \pm 55.5$ \\
HDPE sheet & $1.32 \pm 0.57$ & $0.45 \pm 0.19$ & $0.87 \pm 0.37$ & $189 \pm 65.0$ \\
LDPE sheet & $1.29 \pm 0.56$ & $0.45 \pm 0.20$ & $0.84 \pm 0.35$ & $189 \pm 65.8$ \\
PVC pipe & $0.78 \pm 0.45$ & $0.27 \pm 0.16$ & $0.50 \pm 0.29$ & $154 \pm 51.6$ \\
\hline
\end{tabular}

The paired $t$-test of DW has shown significant difference among all substrates, except for the comparison between HDPE and LDPE; there was no significance observed. Pared sample $t$ has shown significant difference among all the substrate in the periphyton ash content $(p<0.001)$, AFDW, and AI whereas there was no significance observed between the substrate HDPE and LDPE for ash $(p=0.766)$, ash free dry weight, and autotrophic index $(p>0.05)$.

Table 2 Periphyton quantity and quality observed by different authors in different aquatic systems.

\begin{tabular}{|c|c|c|c|c|}
\hline Reference & Aquatic system & Substrate & $\begin{array}{l}\text { Periphyton Quantity } \\
\text { (mg/cm2) }\end{array}$ & $\begin{array}{c}\text { Periphyton Quality } \\
\left(\mu \mathrm{g} / \mathrm{cm}^{2}\right)\end{array}$ \\
\hline Azim et al [21] & Fresh water & Bamboo, Kanchi, Hizol & DW: $2-5$ & Chl a: $2.8-12$ \\
\hline Azim et al [21] & Fresh water & Bamboo, Glass slides & DW: $0.9-2.6$ & Chl a: $2.8-12$ \\
\hline Signor et al [29] & Fresh water & $\begin{array}{l}\text { Fibre glass, Acrylic, Wood, } \\
\text { Ceramic, Glass, Black Plastic }\end{array}$ & $\begin{array}{l}\text { DW (summer): 0.07-0.13 } \\
\text { DW (winter): } 0.067-0.095\end{array}$ & nd \\
\hline $\begin{array}{l}\text { Keshavanath } \\
\text { et al [28] }\end{array}$ & Fresh water & Bamboo, Ambay, Leucaena & nd & Chl a: 39.59 \\
\hline Rai et al [31] & Fresh water & $\begin{array}{l}\text { Split bamboo, Whole bamboo, } \\
\text { Banana midrib, Plastic bottle }\end{array}$ & DW: $0.027-0.043$ & nd \\
\hline Khatoon et al [32] & Brackish water & $\begin{array}{l}\text { Bamboo, PVC pipes, Plastic } \\
\text { sheets, Fibrous scrubber, } \\
\text { Ceramic tiles }\end{array}$ & nd & Chl a: $0.01-0.1$ \\
\hline Richard et al [8] & Marine pond & $\begin{array}{l}\text { Wooden pole, Fibre glass, } \\
\text { Mosquito screen, Garden net }\end{array}$ & $\begin{array}{l}\text { DW: } 1.5-8.8 \\
\text { AFDW: } 0.2-4.5\end{array}$ & Chl a: $0.4-0.6$ \\
\hline Guarientao et al [30] & Coastal lagoon & $\begin{array}{l}\text { Plastic ribbon, Green and } \\
\text { Senescent leaves of Thypa }\end{array}$ & AFDW: 0.8-5.6 & Chl a: $0.12-0.44$ \\
\hline Present study & $\begin{array}{l}\text { Low saline } \\
\text { ground water }\end{array}$ & $\begin{array}{l}\text { Bamboo, Green Shade Net, } \\
\text { HDPE sheets, LDPE sheets } \\
\text { and PVC pipes }\end{array}$ & $\begin{array}{l}\text { DW: } 0.7-1.8 \\
\text { AFDW: } 0.5-1.1\end{array}$ & Chl a: $3.1-6.8$ \\
\hline
\end{tabular}

nd: no data, DW: dry weight, AFDW: ash free dry weight, Chl a: chlorophyll a. 
cement tanks.

The periphytic algal biomass increases exponentially through colonization and growth and reaches a peak with submersion time [17]. The AFDW and chlorophyll a value increases exponentially according to the periphyton colonization model developed by Hoagland et al [18] and Steinman [19]. The development of periphyton biomass on the 3 different substrates was more or less similar during the 3 weeks, at this point, and reached the peak [20]. In the investigation conducted in low saline groundwater, the growth of periphyton was observed as an exponential with time in all 5 different substrates on par with the results obtained by Azim et al $[21,22]$ in freshwater. According to Kirk [23], the intensity of light and the spectral composition have a considerable impact on the quality and composition of flora and periphyton with the change in depth. In contrast to this in the present study, the periphyton composition in 3 different depths $(10,40$, and 70$)$ was observed to have different values, but there was no significant difference observed statistically in all 5 different substrates.

Richard et al [24] observed a variation in the dry weight, ash, ash free dry weight, chlorophyll a, and pheophytin a concentration based on the different substrate types used. Biodegradable materials are found to be more effective in periphyton growth than synthetic substrates based on the study conducted between bamboo and PVC tubes [25]. The same has been reported in the estuary with higher recruitment of epifauna on plywood than on fiberglass or Aluminium substrate [26]. The present study also proves the previous results of higher values of DW, ash, AFDW, and chlorophyll a in bamboo substrate compared to those in green shade net, HDPE, LDPE, and PVC substrates. Bamboo is recommended as a substrate for periphyton growth because of its ability to produce high-quality periphyton, its availability in tropics, ease of use, and durability [27]. The results from this study prove that even under low saline groundwater conditions, bamboo substrate has better periphyton growth compared to the other substrates used in this study. The periphyton quality assessment based on chlorophyll a observed in low saline groundwater was found to be on par with the chlorophyll a values observed from different studies in freshwater [19], and the higher values of chlorophyll a were reported in bamboo [28] (Table 2) as it was observed in the present study with higher periphyton growth in bamboo substrate compared to the other substrates. In contrast, Richard et al [8] have reported higher levels of dry matter and chlorophyll a on meshed substrates (mosquito net and garden net) than on smooth substrate (wood and plywood). The chlorophyll a values observed by different authors in the brackish, coastal lagoon, and marine waters were very less compared to the values documented in freshwater and in the present study (Table 2).
Dry weight obtained in the present investigation was also observed to be the same as reported in freshwater systems by other authors. The AFDW values were observed to be at less quantity than the values reported by Richard et al [8] and Guarientao et al [30]. Considering the taxonomic composition of periphyton in low saline groundwater in the present study, only 5 genera of planktons were observed from the 3 groups, whereas Azim et al [22] have documented 29 genera from 6 groups of planktons, and Rai et al [31] have documented more than 40 genera from 6 groups of planktons in fresh water-based substrates. This fewer species diversification in low saline groundwater reported is due to the impact of salinity as a limiting factor in controlling the growth of microalgae at lower salinity as reported by Khatoon et al [32], and groundwater does not meet the necessary osmotic requirement of the cultured organisms. In groundwater with salinity of $30 \mathrm{ppt}$, mortality of cultured algae and shellfish has been reported in Delta area of South Netherlands [33] due to the deviation in the ionic composition (chloride, sulphate, bicarbonate, sodium, magnesium, calcium, and potassium) compared to that of seawater. The lack of organic inputs such as fertilizers and feed as a source of nutrients in a culture system also limits the growth of plankton in the system. The results from the present investigation have proved that growth of quality periphyton is possible in low saline groundwater for adoption in low saline aquafarming, and it also has proved that under low saline condition, bamboo as a substrate performs better in the production of good quantity and quality periphyton compared to the other substrates used in this study.

Based on this study, the growth and composition of periphyton in low saline groundwater conditions using different substrates have been evaluated, and this study proves the growth of periphyton in low saline conditions. Hence further studies are essential to combine substrate-based aquafarming in low saline groundwater for the adoption of aquaculture to enhance fin and shellfish production in inland areas with saline groundwater lands as an alternative for agriculture.

Acknowledgements: This work was supported by the Tamil Nadu Dr.J. Jayalalithaa Fisheries University for giving this opportunity with the necessary funding for carrying out the research work in service under a part-time $\mathrm{PhD}$ program.

\section{REFERENCES}

1. Sharma NK, Singh M, Rai AK (2021) Salinity: Translating information from model microbes into crop plants. ScienceAsia 47, 131-142.

2. Lakra WS, Reddy AK, Harikrishna V (2014) Manual on Technology for Commercial Farming of Pacific White Shrimp Litopenaeus vannamei in Inland Saline Soils Using Ground Saline Waters, Central Institute of Fisheries Education, India, pp 13. 
3. Wetzel RG (1983) Attached algal-substrata interactions: fact, myth, and when and how?, In: Wetzel RG (ed) Periphyton of Freshwater Ecosystems, Springer, Dordrecht, pp 207-215.

4. Reid GK, Wood RD (1976) Ecology of Inland Waters and Estuaries, 2nd edn, D. van Nostrand Company, New York, USA.

5. Weitzel RL (1979) Periphtyon measurements and applications. In: Weitzal RL (ed) Methods and Measurements of Periphyton Communities. A Review, American Society for Testing and Materials, Special Technical Publication 690, USA, pp 3-33.

6. Azim ME, Verdegem MCJ, Van Dam AA, Beveridge MCM (2005) Periphyton: Ecology, Exploitation and Management, CAB Internation.

7. Miller MW, Falace A (2000) Evaluation methods for trophic resource factors - nutrients, primary production, and associated assemblages. In: Seaman WJr (ed) Artificial Reef Evaluation with Application to Natural Marine Habitats, CRC Press, Boca Raton, Florida, pp 95-126.

8. Richard M, Trottier C, Verdegem MCJ, Hussenot JME (2009) Submersion time, depth, substrate type and sampling method as variation sources of marine periphyton. Aquaculture 295, 209-217.

9. APHA (1992) Standard Methods for the Examination of Water and Wastewater. American Public Health Association, Washington DC.

10. Milstein, Ana Peretz, Yakov Harpaz, Sheenan (2008) Comparison of periphyton grown on different substrates as food for organic Tilapia culture. Isr J Aquacult-Bamid 60, 243-252.

11. Dutta MP, Phukan B, Baishya S, Hussain IA, Kashyap D, Deka P, Roy S (2013) Comparative study of periphyton growth on two different substrates (palm leaf and nylon net). Environ Ecol 31, 1725-1731.

12. Munshi JD, Roy SP, Datta Munshi JS (2010) Manual of Freshwater Biota, Narendra Publishing House, Delhi, India.

13. Boyd CE (2002) Inland farming of marine shrimp: Examples for China, Ecuador, Thailand and the United States. Report prepared under the World Bank, NACA, WWF and FAO Consortium Program on Shrimp Farming and the Environment. Work in Progress for Public Discussion, Published by the Consortium, Bangkok, Thailand.

14. Saoud IP, Davis DA, Rouse DB (2003) Suitability studies of inland well waters for Litopenaeus vannamei culture. Aquaculture 217, 373-383.

15. Van Dam AA, Beveridge MCM, Azim ME, Verdegem MCJ (2002) The potential of fish production based on periphyton. Rev Fish Biol Fish 12, 1-31.

16. Bold HC, Wynne ME (1985) Introduction to the Algae Structure and Reproduction, 2nd edn, Prentice-Hall, Englewood Cliffs, New Jersey.

17. Biggs BJF (1996) Patterns in benthic algaeof streams. In: Stevenson RJ, Bothwell ML, Lowe RL (eds) Algal Ecology: Freshwater Benthic Ecosystems, Academic Press, San Diego, California, pp 31-56.

18. Hoagland KD, Roemer SC, Rosowski JR (1982) Colonization and community structure of two periphyton assemblages with emphasis on the diatoms (Bacillariophyceae). Am J Bot 69, 188-213.

19. Steinman AD (1996) Effect of grazers on freshwater
Benthic algae. In: Stevenson RJ, Bothwell ML, Lowe RL (eds) Algal Ecology, Academic Press, San Diego, California, pp 341-373.

20. Azim ME, Wahab MA, Verdegam MCJ, Van Dam AA, Van Rooij JM, Beveridge MCM (2002) The effect of artificial substrates on freshwater pond productivity and water quality and the implications for periphyton-based aquaculture. Aquat Living Resour 15, 231-241.

21. Azim ME, Verdegem MCJ, Singh M, van Dam AA, Beveridge MCM (2003) The effects of periphyton substrate and fish stocking density on water quality, phytoplankton, periphyton and fish growth. Aquacult Res 34, 685-695.

22. Azim ME, Wahab MA, Van Dam AA, Beveridge MCM, Verdegem MCJ (2001) The potential of periphytonbased culture of two Indian major carps, rohu Labeo rohita (Hamilton) and gonia Labeo gonius (Linnaeus). Aquacult Res 32, 209-216.

23. Kirk JTO (2011) Light and Photosynthesis in Aquatic Ecosystems, 3rd edn, Cambridge University Press, Cambridge, Massachussetts.

24. Richard M, Trottier C, Verdegem M, Hussenot J (2009) Submersion time, depth, substrate type and sampling method as variation sources of marine periphyton. Aquaculture 295, 209-217.

25. Keshavanath P, Gangadhar B, Ramesh TJ, van Dam AA, Beveridge MCM, Verdegem MCJ (2004) Effects of bamboo substrate and supplemental feeding on growth and production of hybrid red tilapia fingerlings (Oreochronis mossambicus $\times$ Oreochromis niloticus). Aquaculture 235, 303-314.

26. Anderson MJ, Underwood AJ (1994) Effects of substratum on the recruitment and development of an intertidal estuarine fouling assemblage. J Exp Mar Biol Ecol 184, 217-234.

27. Azim ME (2001) The potential of periphyton-based aquaculture production systems. $\mathrm{PhD}$ Thesis, Wageningen Univ, Wageningen, The Netherlands.

28. Keshavanath P, Leao da Fonseca FA, Affonso EG, Nobre AD, Jeffson NP (2017) Periphyton growth on three bio-substrates and its influence on the performance of Jaraqui (Semaprochilodus insignis). Int $J$ Aquacult 7, 86-93.

29. Signor A, Signor AA, Boscolo WR, Reidel A, Klein S, Feiden A (2015) Periphyton biomass on artificial substrates during the summer and winter. Ciência Rural, Santa Maria 45, 72-78.

30. Guarientoa RD, Calimana A, Esteves FA, Bozellia RL, Enrich-Prast A, Farjalla VF (2009) Substrate influence and temporal changes on periphytic biomass accrual and metabolism in a tropical humic lagoon. Limnologica 39, 209-218.

31. Rai S, Gharti K, Shrestha M, Ranjan R, Diana J, Egna H (2018) Potential substrates for periphyton enhancement in Carp-SIS polyculture. Our Nature 16, 8-16.

32. Khatoon H, Banerjee S, MdYuso FM, Shari M (2010) Effects of salinity on the growth and proximate composition of selected tropical marine periphytic diatoms and cyanobacteria. Aquacult Res 41, 1348-1355.

33. van der Hiele T, Rijstenbil JW, Creemers J, Heringa J (2014) Composition, Treatment and Use of Saline Groundwater for Aquaculture in the Netherlands, World Aquaculture, The Netherlands. 